\title{
A O.6 Million Year Pollen Record from the Colombian Andes
}

In the basin of Bogotá, located in the Eastern Cordillera of Colombia, continuous subsidence has been in equilibrium with sediment accumulation since the late Pliocene $(1,5)$. This has resulted in a very thick sequence of lake sediments rich in fossil pollen (3). At site Funza $\left(4^{\circ} 50^{\prime} \mathrm{N}, 75^{\circ} 12^{\prime} \mathrm{W}\right)$ deep bore holes were drilled by the Colombian Geological Survey (Ingeominas). The $357 \mathrm{~m}$ long core Funza-I represents the last 1.4 million years (Ma), and the $586 \mathrm{~m}$ long core Funza-II the last 3.2 Ma. Here we show the pollen record of the upper $140 \mathrm{~m}$ of Funza-I core sediments. The originally published time frame of Funza-I $(4,5)$ was revised on the basis of absolute datings of core Funza-II (1). The former lake of Bogotá drained around $25 \mathrm{kyr}$ BP and the present-day high plain at $2550 \mathrm{~m}$ altitude in the eastern Cordillera of Colombia represents the floor of this former lake.

The Colombian Andes show a clear altitudinal zonation of the vegetation: lowland forest from 0 to $1000 \mathrm{~m}$, subandean forest (lower montane forest) from 1000 to $2300 \mathrm{~m}$, and Andean forest (upper montane forest) from 2300 to 3200 $\mathrm{m}$. Above the upper forest line, usually around $3200 \mathrm{~m}$ and corresponding to the $9.5^{\circ} \mathrm{C}$ annual isotherm, subparamo occurs from 3200 to $3500 \mathrm{~m}$, grassparamo from 3500 to $4200 \mathrm{~m}$, and superparamo from $4200 \mathrm{~m}$ to the perennial snow belt at $4800 \mathrm{~m}$. Each of these vegetation belts is characterized by presence or dominance of a suite of taxa. On the basis of the relative contribution of different vegetation belts to the total pollen spectrum, the altitudinal position of the upper forest line can be estimated. Using a lapse rate of $6^{\circ} \mathrm{C}$ temperature change for every 1000 $\mathrm{m}$ displacement of the upper forest line, the paleotemperature for each period can be calculated. In the tropical mountains this is a relatively reliable method as shifts of vegetation belts occur altitudinally over a short range of maximally $1500 \mathrm{~m}$.

Today the high plain lies in the Andean forest belt, $700 \mathrm{~m}$ below the upper forest line, but during colder episodes of the Quaternary, subparamo and even grassparamo surrounded the lake (4). As the altitude of the former lake is halfway between the maximum altitudinal position of the upper forest line
(3400 m, during the warmest interglacial) and its lowest position $(1900 \mathrm{~m}$, during the coldest Pleistocene glacial), the lake sediments provide a sensitive record of climatic change during the entire Quaternary (6).

Time control is based on a visual match with core Funza-II from the same location, that includes absolute fissiontrack ages, and a match with the $\delta^{18} \mathrm{O}$ record of ODP Site 677 (1). In a recent study 73 fossil taxa, present in $>4 \%$ of the 409 pollen assemblages were analysed with TWINSPAN $(7,8)$. We recognized 10 cluster types that form 3 main cluster zones: W (warm), CW (cool), and C (cold). Pollen zones based on previous visual inspection were compared with new cluster types which were graphed as a bar code along the pollen diagram. The use of two pollen sums (standard pollen sum, and a zonal pollen sum) was useful in identifying local effects on the forest composition.

During the period from 650-330 kyr BP Alnus, Hedyosmum, Weinmannia, Melastomataceae, Myrica, and Podocarpus were the most important taxa of the Andean forest. The time frame published in 1993 (1) indicates that the first scattered presence of Quercus started around 478 kyr BP (102 m core depth), the first continuous presence began in $423 \mathrm{kyr} \mathrm{BP}$ (92 $\mathrm{m})$, and the presence of zonal Quercus forest around $330 \mathrm{kyr}$ BP (72 m). During the period from 330-135 kyr BP zonal Quercus and Weinmannia forest developed, replacing partly Podocarpus-dominated forest in the uppermost Andean forest belt. As a consequence, during the last 135 kyr BP high representation of Quercus on the high plain of Bogotá no longer coincides with warm climatic conditions, but now occurs during cool to cold conditions (7). The pollen record was correlated with the $\delta^{18} \mathrm{O}$ record and the temperature drop during OIS 4 and and the very first part of OIS 2 is calculated as minimally $6.6^{\circ}$ to $7.8^{\circ} \mathrm{C}$. The inferred amplitude of the upper forest line during the last $650 \mathrm{kyr}$ was maximally from ca. 1900 to $3400 \mathrm{~m}$ corresponding to a range of ca. $+1.2^{\circ} \mathrm{C}$ to $-7.8^{\circ} \mathrm{C}$ compared to today. Effects of low glacial $\mathrm{pCO}_{2}$ on the altitudinal vegetation distribution are not fully understood at this moment and, as a consequence, not accounted for in the temperature estimates (2).

\section{Henry Hooghiemstra \& Ron van 't Veer}

University of Amsterdam, The Netherlands

hooghiemstra@bio.uva.nl

\section{References}

(1) Andriessen et al., 1993

(2) Boom et al., submitted

(3) Helmens, 1990

(4) Hooghiemstra, 1984

(5) Hooghiemstra, 1989

(6) Hooghiemstra \& Cleef, 1995

(7) Van ' Veer \& Hooghiemstra, submitted

(8) Van 't Veer et al., 1995

Full references can be found at www.pages. unibe.ch/ publications/newsletters/ref993.html

Figure 3: Summary pollen diagram of the core interval 0-140 $\mathrm{m}$ from site Funza-I, located at 2550 m altitude in the Eastern Cordillera of Colombia. This site lies in the Andean forest belt at present (green), but in the past the former lake was surrounded by subparamo or grassparamo vegetation. From left to right are shown:

(1) scale of estimated ages (kyr)

(2) correlation with the marine oxygen isotope stages 2 through 15

(3) core depth $(\mathrm{m})$

(4) arboreal vs. non-arboreal pollen percentages based on 'standard pollen sum'

(5) main pollen diagram based on the 'standard pollen sum' including subandean forest (lower montane forest), andean forest (upper montane forest; Alnus and Quercus have separate curves); subparamo and grassparamo are vegetation belts above the upper forest line. Oak (Quercus) is an immigrant from the northern hemisphere and started its record in the study area at $478 \mathrm{kyr} B P$ but continuous presence of zonal oak forest has occurred since $330 \mathrm{kyr} B P$. (6) main pollen diagram based on a pollen sum of taxa from zonal vegetation types only 'zonal pollen sum'). Compositae, with a relatively wide ecological/altitudinal range, are excluded from the subparamo group. For the same reason grasses are excluded from the grassparamo group that consists here of characteristis herbs only.

(7) pollen diagram based on a pollen sum exclusively including marsh and lake taxa. Shallow water taxa are graphed from the left, deep water taxa from the right. Note that lake-level oscillations coincide to a high degree with glacialinterglacial cycles shown in the two vegetation diagrams. In general cold climates coincide with high lake-levels whereas increased evaporation during warm climatic conditions result in low lake-levels.

(8) Cluster zones (pollen assemblage clusters) result from a modified TWINSPAN-classification and reflect vegetation belts in relation to the present-day altitudinal range of the taxa in each cluster zone. Core intervals reflecting warm, cool, and cold climatic conditions. 


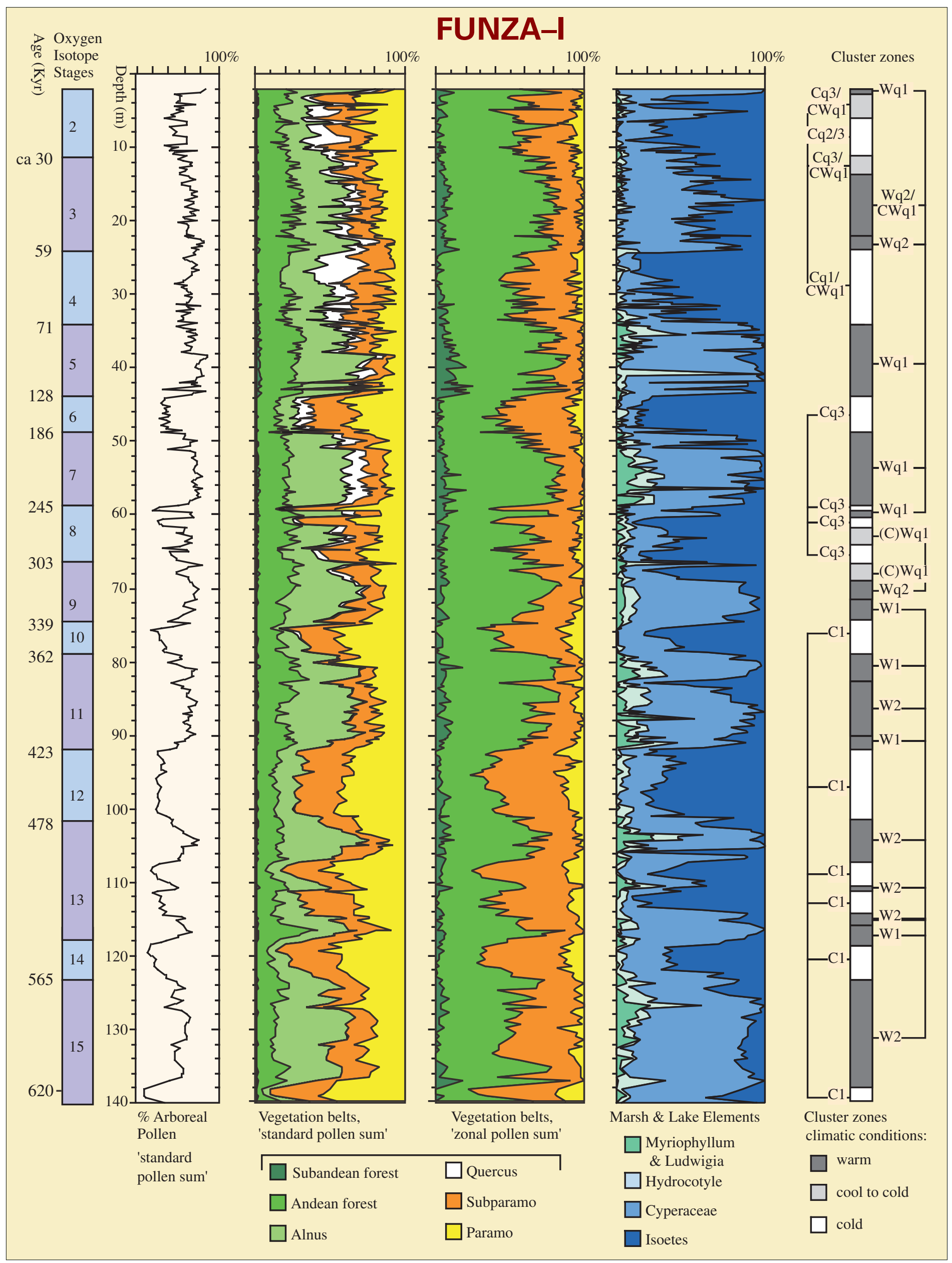

